\title{
Light and scanning electron microscopy of Myxobolus porofilus sp. n. (Myxosporea: Myxobolidae) infecting the visceral cavity of Prochilodus lineatus (Pisces: Characiformes: Prochilodontidae) cultivated in Brazil
}

\author{
Edson A. Adriano ${ }^{1}$, Sarah Arana $^{2}$, Paulo S. Ceccarelli ${ }^{3}$ and Nelson S. Cordeiro ${ }^{1}$ \\ ${ }^{1}$ Departamento de Parasitologia, Instituto de Biologia, Universidade Estadual de Campinas (UNICAMP), Campinas, SP, Brasil; \\ ${ }^{2}$ Departamento de Histologia e Embriologia, Instituto de Biologia, Universidade Estadual de Campinas (UNICAMP), Campinas, \\ SP, Brasil; \\ ${ }^{3}$ Centro Nacional de Pesquisa de Peixes Tropicais (CEPTA/IBAMA), Pirassununga, SP, Brasil
}

Key words: Myxosporea, Myxobolus porofilus, Prochilodontidae, Prochilodus lineatus, Brazil

\begin{abstract}
Myxobolus porofilus sp. n. is described infecting the visceral cavity of Prochilodus lineatus (Valenciennes, 1836) cultivated in São Paulo State, Brazil. The plasmodial form of the parasite is 3-5 $\mathrm{mm}$ in length and appeared compressed between the wall of the visceral cavity and the pyloric caecum, reposing on this organ. The spores are small (length $5.7 \pm 0.3 \mu \mathrm{m}$, width $4.8 \pm 0.2 \mu \mathrm{m}$; mean $\pm \mathrm{SD}$ ) and round to elliptical in frontal view. The valve surfaces are smooth and have sutural folds. The polar capsules are ovoid, small (length $1.6 \pm 0.1 \mu \mathrm{m}$, width $1.1 \pm 0.1 \mu \mathrm{m}$ ) and equal in size. The polar filaments have three turns aligned perpendicularly to the longitudinal axis of the capsule. A conspicuous polar filament pore is arranged at the anterior end of the spore. The only reaction observed upon histological analysis was the presence of a capsule of connective tissue surrounding the plasmodia. This is the first report of a myxosporean parasite in the Prochilodontidae.
\end{abstract}

Wild and cultivated fishes in many regions of the world are infected by numerous myxosporean parasites of the genus Myxobolus Bütschli, 1882. Landsberg and Lom (1991) listed a total of 444 Myxobolus species, most of them found in North American, European and Asiatic fishes. Fomena and Bouix (1997) listed 48 Myxobolus species infecting freshwater fishes in Africa. In South America, 17 Myxobolus species have been reported to parasitise freshwater fishes. During a survey of myxosporean parasites of fish species cultivated in Brazil, we discovered a new species of Myxobolus. The parasite was found in Prochilodus lineatus (Valenciennes, 1836), a teleostean detritivorous species native to South America. This fish species, popularly known as curimba or curimbatá, is widely distributed in South American rivers and attains a relatively large size, with some specimens measuring $75 \mathrm{~cm}$ in length and weighing $8.2 \mathrm{~kg}$ (Godoy 1975). The curimba is one of the most consumed fish species in Brazil and is the principal source of income for fisheries in several regions of the country. This species' high reproductive capacity, its rapid growth, its detritivorous habit, i.e., the ingestion of mud, which reduces the requirement for feeding, and its widespread acceptance on the market, have all contributed to the increased interest in its cultivation in fish farms throughout Brazil.

\section{MATERIALS AND METHODS}

Specimens of Prochilodus lineatus (curimba), Piaractus mesopotamicus (Holmberg, 1887) (pacu), Brycon cephalus (Günther, 1869) (matrinxã) and Leporinus copelandii Steindachner, 1875 (piau), four months old, were released in a pond at the National Center for Research in Tropical Fishes located in the municipality of Pirassununga, State of São Paulo, Brazil. Five specimens of each species were examined monthly for the presence of myxozoan parasites from March 2000 to February 2002. Immediately after collection, the fishes were transported alive to the laboratory where they were killed by transection of the spinal cord, before being measured, weighed and necropsied. When plasmodia were present, they were measured with a ruler. The measurements of 32 fresh mature spores (Lom and Arthur 1989) were obtained using a micrometer incorporated into the microscope eyepiece. The dimensions were expressed as the mean \pm standard deviation (SD). India ink was used to detect the presence of a mucus envelope around the spores. The spores were checked for the presence of an iodophilous vacuole after adding a drop of Lugol solution. Smears containing free spores were stained with Giemsa's solution and mounted in mounting medium of low viscosity $\left(\right.$ Cytoseal $\left.^{\mathrm{TM}}\right)$ as permanent preparations. For histological analysis, the plasmodia were fixed in $10 \%$ buffered formalin for $24 \mathrm{~h}$, embedded in paraffin, cut into sections $4 \mu \mathrm{m}$ thick and stained with haematoxylin and eosin or sirius red, a stain developed by

Address for correspondence: N.S. Cordeiro, Departamento de Parasitologia, Instituto de Biologia, Universidade Estadual de Campinas (UNICAMP), Caixa Postal 6109, CEP 13083-970, Campinas, São Paulo, Brasil. Phone: ++55 19 3788-6284; Fax: ++55 19 3788 6282; E-mail: nsilvac@unicamp.br 


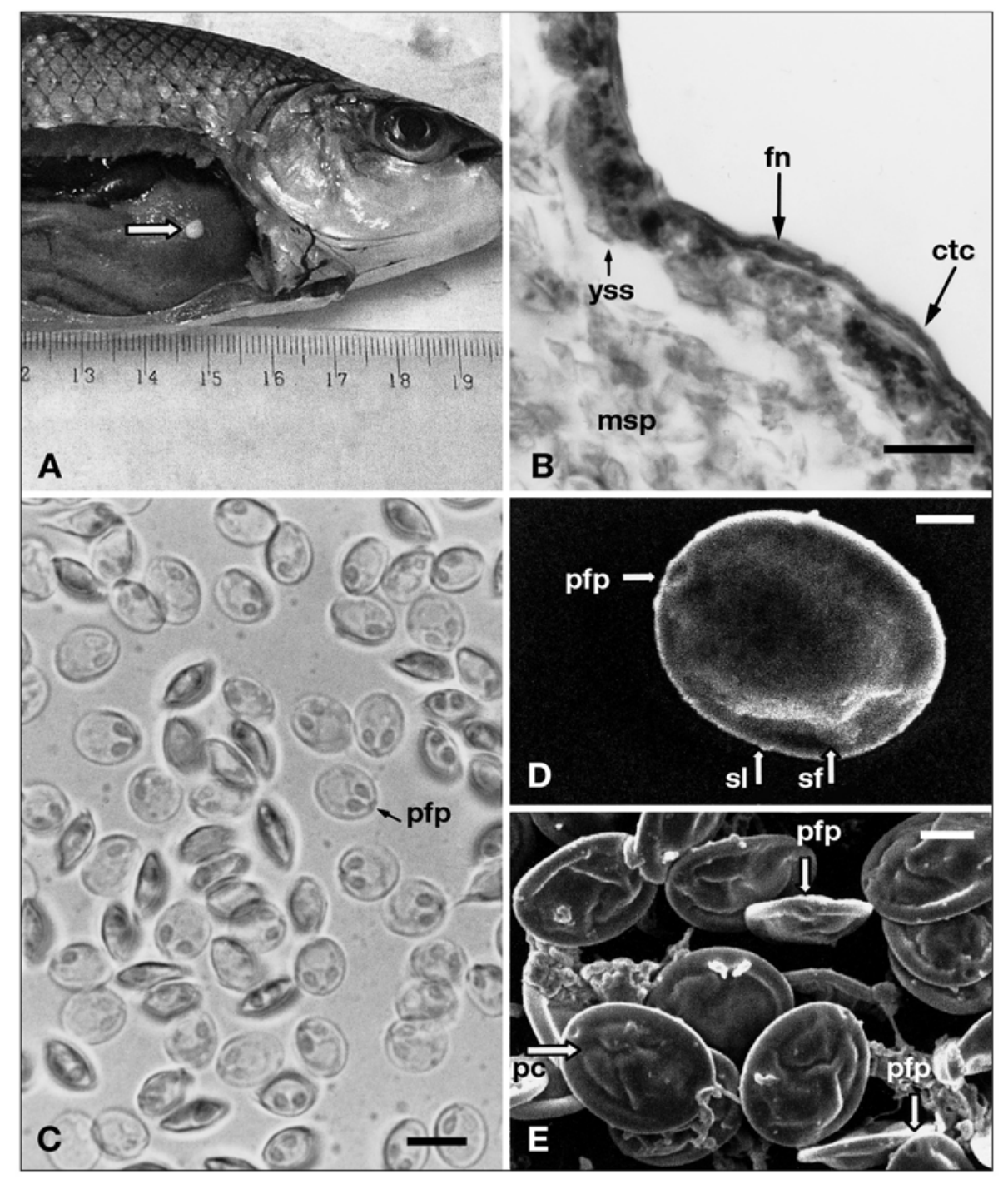

Fig. 1. Myxobolus porofilus sp. n. in the visceral cavity of Prochilodus lineatus. A - Plasmodium on the pyloric caecum of a young fish. B - Histological section of a plasmodium. Sirius red stain. $\mathbf{C}-$ Photomicrograph of spores in a fresh preparation. $\mathbf{D}$ - Scanning electron micrograph of a spore processed by method 1. $\mathbf{E}$ - Scanning electron micrograph of spores processed by method 2. Note that the spores appear shrunken, probably because of processing artefact. Abbreviations: ctc - connective tissue capsule; fn - fibrocyte nucleus; msp - mature spores; pfp - polar filament pore; pc - polar capsules; sf - sutural folds; sl - robust suture line; yss - young sporogonic stages. Scale bars: $B=10 \mu \mathrm{m} ; \mathrm{C}=5 \mu \mathrm{m} ; \mathrm{D}=1 \mu \mathrm{m} ; \mathrm{E}=2 \mu \mathrm{m}$.

Montes and Junqueira (1991) to study the distribution of collagen fibres. For scanning electron microscopy, two methods were used: (1) Free spores were deposited on a coverslip coated with poly-L-lysine and fixed with $2.5 \%$ glutaraldehyde in $0.1 \mathrm{M}$ sodium cacodylate buffer $(\mathrm{pH} 7.2)$ for $2 \mathrm{~h}$ at room temperature. After washing in the same buffer, the preparations were dehydrated in ethanol, critical-point dried, coated with metallic gold and examined in a JEOL JSM-5900LV microscope operated at $30 \mathrm{kV}$. (2) Histological sections of a plasmodium fixed and embedded using routine histological procedures were deposited on a coverslip coated with albumin, dried in stove for $48 \mathrm{~h}$, deparaffinized with xylol, dehydrated in ethanol, critical-point dried, coated with metallic gold and examined as above.

\section{RESULTS}

Of the four fish species studied, only three (2.5\%) specimens of $P$. lineatus had plasmodia containing spores of an undescribed myxosporean species belonging to the genus Myxobolus. The infected fish were examined in August 2000 and had one or two plasmodia compressed between the wall of the visceral cavity and the pyloric caecum, reposing on this organ (Fig. 1A). 

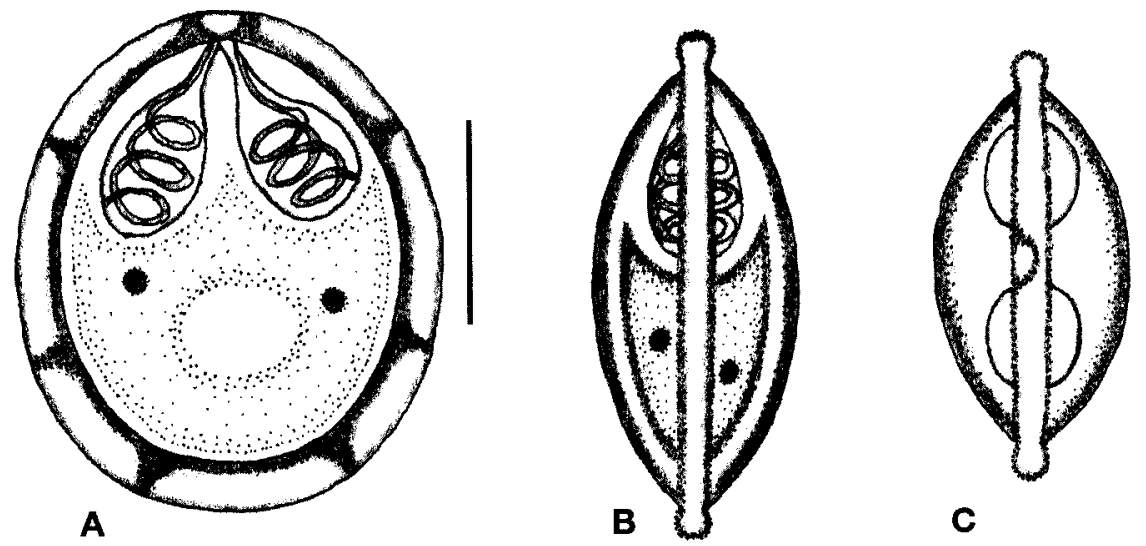

Fig. 2. Schematic representation of mature spores of Myxobolus porofilus sp. $\mathrm{n}$. A - frontal view, B - lateral view, $\mathbf{C}-$ apical view of anterior end. Scale bar $=3 \mu \mathrm{m}$.

\section{Myxobolus porofilus sp. $\mathrm{n}$.}

Figs. 1, 2

Plasmodial form 3-5 $\mathrm{mm}$ in size, white, spherical and polysporic, with spores in different developmental stages. Histologically, the only host reaction detected was the formation of a thin $(2.0 \mu \mathrm{m})$ connective tissue capsule around the plasmodia (Fig. 1B). Young sporogonic stages present in ectoplasm, with a larger number of mature spores in the endoplasm (Fig. 1B).

Spores small (length $5.7 \pm 0.3 \mu \mathrm{m}$, width $4.8 \pm 0.2$ $\mu \mathrm{m})$ and sub-spherical in frontal view (Figs. 1C, E and 2). Valve walls smooth, symmetrical with sutural folds (Fig. 1D, E). In lateral view, spores discus-shaped (Figs. 1D, 2B); suture line emerges well over surface (Fig. 1D, E). A conspicuous polar filament pore situated on one side of sutural line, at anterior end (Fig. 1C-E). Polar capsules ovoid in shape, small and equal in size (length $1.6 \pm 0.1 \mu \mathrm{m}$, width $1.1 \pm 0.1 \mu \mathrm{m}$ ). Anterior ends of po-lar capsules closed; ratio of capsule length to spore length about 1:3. Polar filaments with three turns aligned perpendicularly to longitudinal axis of capsule (Fig. 2). A large, round vacuole present in sporoplasm and two nuclei discernible in unstained and Giemsastained pre-parations. No mucus envelope was seen after treatment with India ink.

T y p e h o s t: Prochilodus lineatus (Valenciennes, 1836) (Pisces, Characiformes, Prochilodontidae).

$\mathrm{S}$ i t e of i n f e c t i o $\mathrm{n}$ : Compressed between the wall of the visceral cavity and the pyloric caecum, reposing on the pyloric caecum.

P r e v a l e n c e : $3 / 120(2.5 \%)$ of $P$. lineatus were infected.

L o c a 1 i t y : National Center for Research in Tropical Fishes (CEPTA/IBAMA), Pirassununga, State of São Paulo, Brazil.

T y p e m a t e r i a 1: Slides with stained spores (syntype) have been deposited in the collection of the Museum of Natural History, Institute of Biology, State University of Campinas (UNICAMP), State of São Paulo, Brazil (accession numbers ZUEC 04 and 05).
E t y m o lo $\mathrm{g}$ y: The specific name is a combination of the words poro (derived from the Greek poros $=$ hole) and filus (from the Latin filus $=$ filament) in reference to the conspicuous polar filament pore.

\section{DISCUSSION}

Myxobolus porofilus was compared with all Myxobolus species previously reported in South American fishes. Only Myxobolus macroplasmodialis Molnár, Ranzani-Paiva, Eiras et Rodrigues, 1998, reported to have been found free in the visceral cavity of Salminus maxillosus (Characidae) (Molnár et al. 1998), and Myxobolus absonus Cellere, Cordeiro et Adriano, 2002, reported to have been found free in the opercular cavity of Pimelodus maculatus (Pimelodidae) (Cellere et al. 2002), resembled the species described here with regard to the site of infection (not incorporated in the host tissues) and the colour and structure of the plasmodia. The spores of $M$. porofilus are smaller than those of $M$. macroplasmodialis and $M$. absonus, and the polar capsules are small, of equal size and convergent anterior end (the polar capsules are of unequal size in $M$. absonus and the anterior end is divergent in $M$. macroplasmodialis). M. porofilus also has a conspicuous polar filament pore at the anterior end of one side of the sutural line. In addition to these features, $M$. porofilus was found in a host species of another family. According to Molnár et al. (1998), although little is known about the host specificity of Myxobolus species, the number of species with a large host range is low and most species appear to be strictly host-specific or capable of developing only in closely related fishes. The specimens of $P$. lineatus examined in this study were confined to a pond with two fish species of the family Characidae (B. cephalus and P. mesopotamicus) and one of the family Alostomidae (L. copelandii). However, $M$. porofilus was detected only in specimens of $P$. lineatus, indicating a possible host specificity, at least at 
the family level. Based on the morphological characteristics of the spores and plasmodia, the site of infection and the fact that this is the first report of a Myxobolus sp. in a species of the family Prochilodontidae, we consider $M$. porofilus to be a new myxosporean species.

The plasmodia of $M$. porofilus were found compressed between the wall of the visceral cavity and the pyloric caecum, but the site of initial development is unknown. Molnár et al. (1998) suggested that the initial development of $M$. macroplasmodialis occurred in the serous membrane of the visceral cavity or abdominal organs, and became detached from these sites only at an advanced stage of development. The same cycle may apply to the development of $M$. porofilus, with the serous membrane of the visceral cavity or more probably the pyloric caecum being the site of initial development since the plasmodia were always found reposing on this organ.
The prevalence and intensity of $M$. porofilus was low, with only $2.5 \%$ of $P$. lineatus being infected and the specimen with the highest parasitaemia had only two plasmodia, making it difficult to draw conclusions about the epidemiology of this parasite. The fact that $M$. porofilus was found only in specimens examined in the winter initially suggested a seasonal incidence. However, since this parasite was not detected in fish examined in the winter of 2001, it is possible that only young fish are susceptible to infection.

Acknowledgements. The authors thank the Laboratório de Microscopia Eletrônica at the Laboratório Nacional de Luz Síncrotron, Campinas, SP, for use of the electron microscope. This work is a part of the doctor thesis by Edson A. Adriano and was supported by CAPES.

\section{REFERENCES}

FOMENA A., BOUIX G. 1997: Myxosporea (Protozoa: Myxozoa) of freshwater fishes in Africa: keys to genera and species. Syst. Parasitol. 37: 161-178.

GODOY M.P. 1975: Peixes do Brasil. Subordem Characidae, Bacia do Rio Mogi-Guassu. Editora Franciscana, São Paulo, 847 pp.

LANDSBERG J.H., LOM J. 1991: Taxonomy of the genera of the Myxobolus/Myxosoma group (Myxobolidae: Myxosporea), current listing of species and revision of synonyms. Syst. Parasitol. 18: 165-186.
LOM J., ARTHUR J.R. 1989: A guideline for the preparation of species description in Myxosporea. J. Fish Dis. 12: 151-156.

MOLNÁR K., RANZANI-PAIVA M.J., EIRAS J.C., RODRIGUES E.L. 1998: Myxobolus macroplasmodialis sp. n. (Myxozoa: Myxosporea), a parasite of the celomatic cavity of the characid teleost, Salminus maxillosus, in Brazil. Acta Protozool. 37: 241-245.

MONTES G.S., JUNQUEIRA L.C.U. 1991: The use of the picrosirius-polarization method for the study of the biopathology of collagen. Mem. Inst. Oswaldo Cruz 86: (Suppl. III) 1-11.

Accepted 22 April 2002 